University of Nebraska - Lincoln

DigitalCommons@University of Nebraska - Lincoln

Publications, Agencies and Staff of the U.S.

Department of Commerce

U.S. Department of Commerce

4-1989

\title{
A Porpoise, Australophocaena dioptrica, Previously Identified As Phocoena spinipinnis, From Heard Island
}

Robert L. Brownell Jr.

U.S. Fish and Wildlife Service, rlbcetacea@aol.com

John Heyning

$\mathrm{N}$, a tural History Museum of Los Angeles County, 900 Exposition Blvd., Los Angeles, California

William Perrin

Southwest Fisheries Center

Follow this and additional works at: https://digitalcommons.unl.edu/usdeptcommercepub

Part of the Environmental Sciences Commons

Brownell, Robert L. Jr.; Heyning, John; and Perrin, William, "A Porpoise, Australophocaena dioptrica, Previously Identified As Phocoena spinipinnis, From Heard Island" (1989). Publications, Agencies and Staff of the U.S. Department of Commerce. 85.

https://digitalcommons.unl.edu/usdeptcommercepub/85

This Article is brought to you for free and open access by the U.S. Department of Commerce at DigitalCommons@University of Nebraska - Lincoln. It has been accepted for inclusion in Publications, Agencies and Staff of the U.S. Department of Commerce by an authorized administrator of DigitalCommons@University of Nebraska - Lincoln. 
This article is a U.S. government work, and is not subject to copyright in the United States.

MARINE MAMMAL SCIENCE, 5(2):193-195 (April 1989)

(C) 1989 by the Society for Marine Mammalogy

\section{A PORPOISE, AUSTRALOPHOCAENA DIOPTRICA, PREVIOUSLY IDENTIFIED AS PHOCOENA SPINIPINNIS, FROM HEARD ISLAND}

Guiler, Burton and Gales (1987) reported a cranium (Tasmanian Museum No. A1411) they identified as belonging to Burmeister's porpoise, Phocoena spinipinnis Burmeister, 1865 from Heard Island $\left(53^{\circ} \mathrm{S} 73^{\circ} 30^{\prime} \mathrm{E}\right)$. They noted that $P$. spinipinnis was previously known only from the cold-temperate coastal waters of South America and claimed that this cranium was evidence that the species has a much wider distribution than previously known. We have examined the photographs and details of their specimen and re-identify it here as Australopbocaena dioptrica (Lahille, 1912) (family Phocoenidae).

Barnes (1985) listed several features that distinguish the skulls of species within the subfamily Phocoenoidinae (including $A$. dioptrica) from those species within the Phocoeninae (including Phocoena spp.). Features that distinguish $A$. dioptrica from $P$. spinipinnis, clearly visible in the published photographs of the cranium from Heard Island, include: a relatively small, oval-shaped temporal fossa; an elevated, high-vaulted braincase that slopes abruptly onto the narial region; relatively large, high and convex premaxillary bosses; dorso-ventrally expanded zygomatic process of the squamosal; short and anteroposteriorly expanded postorbital process of the frontals; and maxillae extending nearly to the dorsal margin of the supraoccipital on the top of the skull. In all these features, the Heard Island specimen conforms with those of $A$. dioptrica. Crania of $A$. dioptrica have been illustrated by Hamilton (1941), Norris and McFarland (1958), Brownell (1975), Fordyce et al. (1984), and Barnes (1985). Crania of P. spinipinnis have been illustrated by Norris and McFarland (1958) and Brownell and Praderi (1984).

While Pbocoena spinipinnis and Australophocaena dioptrica overlap in adult skull length, the Heard Island specimen is larger than any known specimen of $P$. spinipinnis. The condylobasal length (CBL) of this cranium is $303 \mathrm{~mm}$; CBL in 10 specimens of $P$. spinipinnis examined by Brownell and Praderi (1984) was 224 to $290 \mathrm{~mm}$. The same measurement for 46 adult skulls of $A$. dioptrica ranged from 279 to $324 \mathrm{~mm}$ (unpublished data, WFP).

Guiler $e t$ al. (1987) based their identification of the newly discovered specimen 
on a comparison of the photographs of phocoenid skulls presented by Norris and McFarland (1958). They noted that although the cranium from Heard Island was larger than the specimen of $P$. spinipinnis shown by Norris and McFarland (1958), "the ratio of rostral width : rostral length (0.513) is similar to that found by those two authors $(0.517)$ as is the ratio of skull length : skull width (0.55 compared to 0.560$)$. These ratios are different from those found for $P$. sinus ( 0.630 and 0.637 respectively) and for $P$. phocaena [sic] $(0.470$ and 0.537 ). The rostral proportions for $A$. dioptrica are $0.737 . "$

The ratio of the width to length of the rostrum of the cranium from Heard Island is given by Guiler $e t$ al. (1987) as 0.513 , but, based on the measurements given in their table 1 , it is actually 0.506 ( 82 divided by 162). Moreover, the rostral length of the Heard Island specimen $(162 \mathrm{~mm}$ ) given in this table must be incorrect. If the zygomatic width and the maximum width are both 169 $\mathrm{mm}$, then it can be seen in figure 2 of Guiler $e t$ al. (1987) that the rostral length is only about $75 \%$ of the maximum width, or approximately $127 \mathrm{~mm}$. This new value for the rostral length of the cranium would give a width to length ratio of 0.646 . This ratio would be greater if the rostral length were less. To obtain a rostral length as great as $162 \mathrm{~mm}$, the measurement would necessarily have been made from the tip of the rostrum to the external nares; and we believe that the rostral length measurement must have been made in this way. The correct ratio of approximately 0.646 , therefore, is closer to that of $A$. dioptrica than $P$. spinipinnis.

The ratio of skull width to the total length of the cranium is 0.558 (not 0.550 as given by Guiler $e t a l$.). The same ratio in the specimens reported by Norris and McFarland (1958) for P. spinipinnis is 0.615 (168 divided by 273) and 0.583 for $A$. dioptrica. Again the ratio of the specimen from Heard Island is closer to that of $A$. dioptrica than to that of $P$. spinipinnis.

We are not able to comment on the rostral alveolar count (14 left and 13 right) given for the Heard Island specimen, except to say that a few extra teeth in each tooth row would yield a number corresponding to the lower end of the range for $A$. dioptrica ( $16-25$ in ten specimens recently examined by WFP). The posterior-most teeth in this species are in a shallow aveolar groove and are easily lost and their numbers very difficult to determine from dry specimens.

Specimens of $A$. dioptrica have been previously reported from Uruguay, Argentina, southern Chile, the Falkland Islands (Malvinas), South Georgia, the Auckland Islands and Macquarie Island (Brownell 1974, Baker 1977, Goodall and Cameron 1979, Fordyce et al. 1984). At-sea sightings of the species are known from around New Zealand and Kerguelen Islands (Frost and Best 1976, Fordyce et al. 1984). Thus, the specimen reported by Guiler et al. (1987), which we identify as $A$. dioptrica, extends the known distribution of the species, which is in the cool-temperate waters of the southern ocean in subarctic latitudes. It will be interesting if future records fill in this scattered distribution record.

Phocoena spinipinnis remains a species of southern South America (coastal waters of southern Brazil-Pinedo, in press; Uruguay, Argentina, Chile and Peru-Brownell and Praderi 1984). The species is not even known from the Falkland Islands, where two other dolphins inhabiting the South American 
mainland coastal waters (Cephalorbynchus commersonii and Lagenorhynchus australis) are known (Brownell 1974).

We thank L. G. Barnes and K. Ralls for useful comments on this manuscript. E. R. Guiler kindly provided phorographs of his Heard Island specimen. The unpublished cranial data for $A$. dioptrica were collected as part of a study in progress by WFP, R. N. P. Goodall and M. Cozzuol.

\section{Literature Cited}

BAKER, A. N. 1977. Spectacled porpoise, Phocoena dioptrica, new to the subantarctic Pacific Ocean. New Zealand Journal of Marine and Freshwater Research 11:401406.

BARnes, L. G. 1985. Evolution, taxonomy and antitropical distributions of the porpoises (Phocoenidae, Mammalia). Marine Mammal Science 1:149-165.

Brownell, R. L., JR. 1974. Small odontocetes of the Antarctic. Pages 13-19 in V. C. Bushnell, ed. Antarctic mammals, Folio 18, Antarctic Map Folio Series, American Geographical Society, New York.

Brownell, R. L., JR. 1975. Phocoena dioptrica. Mammalian Species 66:1-3.

BROWNeLl, R. L., JR., AND R. PRADER1. 1984. Pbocoena spinipinnis. Mammalian Species $217: 1-4$

Fordyce, R. E., R. H. Matiln and J. M. Dixon. 1984. Second record of spectacied porpoise from subantarctic southwest Pacific. Scientific Reports of the Whales Research Institute 35:159-164.

Frost, P. G. M., AND P. B. Best. 1976. Design and application of a coded format for recording observations of cetaceans at sea. South African Journal Antarctic Research $6: 9-14$.

Goodnll, R. N. P., AND I. S. Cameron. 1979. Phocoena dioptrica, una nueva especie para aguas chilenas. Revista del Museo Argentino de Ciencias Naturales, "Bernardino Rivadavia." Zoología 12(11):143-152.

Guiler, E. R., H. R. Burton and N. J. Gales. 1987. On three odontocete skulls from Heard Island. Scientific Reports of the Whales Research Institute 38:117124.

Hamilton, J. E. 1941. A rare porpoise of the South Atlantic, Phocoena dioptrica (Lahille, 1912). Discovery Reports 21:222-234 + 2 plates.

Norris, K. S., AND W. N. MCFARLAND. 1958. A new harbor porpoise of the genus Phocoena from the Gulf of California. Journal of Mammalogy 39:22-39.

Pinedo, M. C. In press. Primeiro registro de Pbocoena spinipinnis (Cetacea, Phocoenidae) para o litoral do Rio Grande do Sul, Brasil, com medidas osteológicas e análise do conteúdo estomacal. Revista Atlantica.

Robert L. Browneli, JR., U.S. Fish and Wildlife Service, P.O. Box 70, San Simeon, California 93428; John E. Heyning, Natural History Museum of Los Angeles County, 900 Exposition Blvd., Los Angeles, California 90007; Wrwam F. Perrin, Southwest Fisheries Center, P.O. Box 271, La Jolla, California 92038. Received June 15, 1988. Accepted November 29, 1988. 